\title{
A Study on Common Visualization Methods for Secret Writing done by Invisible Inks and their Sensitivity Over a Period of Time
}

\author{
Hussain SS and Sahu M* \\ Department of Forensic Science, Guru Ghasidas \\ Vishwavidyalaya, Bilaspur-492010, Chhattisgarh, India \\ *Corresponding author: Manju Sahu, Department \\ of Forensic Science, Guru Ghasidas Vishwavidyalaya, \\ Bilaspur-492010, Chattisgarh, India
}

Received: March 29, 2017; Accepted: April 20, 2017; Published: May 10, 2017

\begin{abstract}
Secret writing is a skill of concealed writing. The art of secret writing is projected to make the written text unreadable by other person who is exposed or deciphered by different revealing process to make the messages readable. Techniques of secret writing are many, but this paper mainly focuses on the use of invisible inks. The current study comprises of secret writing samples which contain hidden messages written using some fruit juices (lemon, apple and grape juice), chemical fluids (detergent, sugar solution and vinegar) and biological fluids (milk, saliva and sweat). They were then visualized using common physical and chemical methods in a specific interval of time; examined from $1^{\text {st }}$ day to $30^{\text {th }}$ day after regular interval of five days. Heating and lodine fuming were found to be the best methods for visualizing invisible inks, among physical and chemical methods, respectively. Both of these methods showed good results up to one month.
\end{abstract}

Keywords: Secret writing; Hidden messages; Invisible ink; Deciphered; Forensic science

\section{Introduction}

Secret writing is any means of written communication whereby a spy conceals the actual written text, whether it is enciphered or encoded or not [1]. It is the art of covered or hidden writing [2]. Techniques of secret writing include use of invisible inks, carbon copies, miniature writings, latent photographs, codes and ciphers. Among these, the use of invisible inks is the most primitive method; others are the result of developments in the field of secret writing with the advancement of time. Invisible inks are also known as Sympathetic inks or Security inks [3]. It is a liquid used to create concealed messages that don't seem unless uncovered by a noteworthy procedure. Invisible inks can be ordered into three principle classes: those that are uncovered by heat, those uncovered by chemical reactions and those that are instantly recognizable under ultraviolet light [4]. The nature of the inks varies tremendously. It may be a simple substance, like water, body secretions, fruit juice, soap, etc. On the other hand, they may be highly complex chemicals. Generally, organic fluids and sympathetic inks are classified as invisible inks. Organic fluids include lemon juice, sweat, saliva, vinegar, milk, onion juice, urine, diluted blood and can be developed through heat. These fluids alter the fibers of the paper and when exposed to heat at lower temperature, the secret writing turns brown faster than the surrounding paper. On the other hand sympathetic ink contains at least one chemical and requires the utilization of a particular "reagent" to be developed [5]. Invisible ink is one form of steganography i.e. concealing a message. The experiment of secret writing comprises of dipping a paint brush in fruit juice, biological fluids and different chemicals and writing on a piece of blank white paper. At the point when the "ink" dries, it will be undetectable to the bare eye, however in the event that the paper is held up to a direct warmth source, for example, a light, a radiator or an iron utilizing UV light to disentangling imperceptible composition. Some basic invisible inks are diluted fruit juices, vinegar and clothing cleanser, all which can be connected by a paintbrush, special invisible ink pen or even a toothpick. Historically, invisible inks were utilized as a part of times of war by governments and extremists alike [4]. The utilization of secret writing has declined since the middle of the twentieth century for some reasons, most critical of which is the sheer volume of information that knowledge administrations must transmit and process [6]. Secret writings are also employed by international spy rings [3]. The inclusion of codes and ciphers under secret writing has been disputed sometimes as they just hide the meaning of a message, unlike secret writing which hides the original message [6].

\section{Materials and Methods}

The present study was carried out at Department of Forensic Science, Guru Ghasidas Vishwavidyalaya, Bilaspur (Chattisgarh) to study the common visualization methods for secret writing done by invisible inks and to find out the sensitivity of these methods over a period of time. Fruit juices (lemon juice, grape juice, apple juice), chemical fluids (vinegar, sugar solution, detergent), and biological fluids (sweat, saliva, milk) were used as invisible ink in the present study. A4 size blank papers were utilized for preparing secret writing samples and a ball point pen without ink, was used as a writing instrument. The nib of this pen was dipped in the required invisible ink and messages were written over the blank paper. The papers with secret messages were marked at the top, with date of sample preparation, name of the invisible ink and the respective day on which it needs to be examined. Extra samples of secret messages were also prepared in the same manner. The papers containing written messages were kept under a running fan, so that the inks dry up 
Table 1: Fruit juices visualized by physical and chemical methods.

\begin{tabular}{|c|c|c|c|c|c|c|}
\hline S. No. & Fluids & Sample & Physical Methods & $\begin{array}{l}\text { Result } \\
\text { Yes/No }\end{array}$ & $\begin{array}{l}\text { Chemical } \\
\text { Methods }\end{array}$ & $\begin{array}{l}\text { Result } \\
\text { Yes/No }\end{array}$ \\
\hline 1 & \multirow{3}{*}{ Fruit Juices } & Lemon juice & $\begin{array}{l}\text { Heat } \\
\text { UV-Short } \\
\text { UV-Long }\end{array}$ & $\begin{array}{l}\text { Yes } \\
\text { Yes } \\
\text { Yes }\end{array}$ & $\begin{array}{l}\text { Phenolphthalein } \\
\text { Silver nitrate } \\
\text { lodine fuming }\end{array}$ & $\begin{array}{l}\text { Yes } \\
\text { Yes } \\
\text { Yes }\end{array}$ \\
\hline 2 & & Apple juice & $\begin{array}{l}\text { Heat } \\
\text { UV-Short } \\
\text { UV-Long }\end{array}$ & $\begin{array}{l}\text { Yes } \\
\text { Yes } \\
\text { Yes }\end{array}$ & $\begin{array}{l}\text { Phenolphthalein } \\
\text { Silver nitrate } \\
\text { lodine fuming }\end{array}$ & $\begin{array}{l}\text { No } \\
\text { Yes } \\
\text { Yes }\end{array}$ \\
\hline 3 & & $\begin{array}{l}\text { Grape } \\
\text { Juice }\end{array}$ & $\begin{array}{l}\text { Heat } \\
\text { UV-Short } \\
\text { UV-Long }\end{array}$ & $\begin{array}{l}\text { Yes } \\
\text { Yes } \\
\text { Yes }\end{array}$ & $\begin{array}{l}\text { Phenolphthalein } \\
\text { Silver nitrate } \\
\text { lodine fuming }\end{array}$ & $\begin{array}{l}\text { No } \\
\text { No } \\
\text { Yes }\end{array}$ \\
\hline
\end{tabular}

Table 2: Chemical fluids deciphered by physical and chemical methods.

\begin{tabular}{|c|c|c|c|c|c|c|}
\hline S. No. & Fluids & Sample & Physical Methods & $\begin{array}{l}\text { Result } \\
\text { Yes/No }\end{array}$ & Chemical Methods & $\begin{array}{l}\text { Result } \\
\text { Yes/No }\end{array}$ \\
\hline 1 & \multirow{3}{*}{ Chemical fluids } & Detergent & $\begin{array}{l}\text { Heat } \\
\text { UV-Short } \\
\text { UV-Long }\end{array}$ & $\begin{array}{l}\text { Yes } \\
\text { Yes } \\
\text { Yes }\end{array}$ & $\begin{array}{c}\text { Phenolphthalein } \\
\text { Silver nitrate } \\
\text { Iodine fuming }\end{array}$ & $\begin{array}{l}\text { Yes } \\
\text { Yes } \\
\text { Yes }\end{array}$ \\
\hline 2 & & Sugar solution & $\begin{array}{l}\text { Heat } \\
\text { UV-Short } \\
\text { UV-Long }\end{array}$ & $\begin{array}{l}\text { Yes } \\
\text { No } \\
\text { No }\end{array}$ & $\begin{array}{l}\text { Phenolphthalein } \\
\text { Silver nitrate } \\
\text { lodine fuming }\end{array}$ & $\begin{array}{l}\text { No } \\
\text { No } \\
\text { No }\end{array}$ \\
\hline 3 & & Vinegar & $\begin{array}{l}\text { Heat } \\
\text { UV-Short } \\
\text { UV-Long }\end{array}$ & $\begin{array}{l}\text { Yes } \\
\text { No } \\
\text { No }\end{array}$ & $\begin{array}{l}\text { Phenolphthalein } \\
\text { Silver nitrate } \\
\text { Iodine fuming }\end{array}$ & $\begin{array}{l}\text { No } \\
\text { No } \\
\text { Yes }\end{array}$ \\
\hline
\end{tabular}

Table 3: Biological fluids visualized by physical and chemical methods.

\begin{tabular}{|c|c|c|c|c|c|c|}
\hline S. No. & Fluids & Sample & $\begin{array}{l}\text { Physical } \\
\text { Methods }\end{array}$ & $\begin{array}{l}\text { Result } \\
\text { Yes/No }\end{array}$ & $\begin{array}{l}\text { Chemical } \\
\text { Methods }\end{array}$ & $\begin{array}{l}\text { Result } \\
\text { Yes/No }\end{array}$ \\
\hline \multirow{3}{*}{1} & \multirow{9}{*}{$\begin{array}{l}\text { Biological } \\
\text { Fluids }\end{array}$} & \multirow{3}{*}{ Milk } & Heat & Yes & Phenolphthalein & Yes \\
\hline & & & UV-Short & Yes & Silver nitrate & Yes \\
\hline & & & UV-Long & Yes & lodine fuming & Yes \\
\hline \multirow{3}{*}{2} & & \multirow{3}{*}{ Saliva } & Heat & Yes & Phenolphthalein & No \\
\hline & & & UV-Short & Yes & Silver nitrate & Yes \\
\hline & & & UV-Long & Yes & lodine fuming & Yes \\
\hline \multirow{3}{*}{3} & & \multirow{3}{*}{ Sweat } & Heat & Yes & Phenolphthalein & Yes \\
\hline & & & UV-Short & Yes & Silver nitrate & Yes \\
\hline & & & UV-Long & Yes & lodine fuming & Yes \\
\hline
\end{tabular}

Table 4: Fruit juices- Visibility with the use of physical methods.

\begin{tabular}{|c|c|c|c|c|c|c|c|c|c|}
\hline & \multicolumn{3}{|c|}{ Lemon juice } & \multicolumn{3}{|c|}{ Apple juice } & \multicolumn{3}{|c|}{ Grape juice } \\
\hline & Heat & UV-Long & UV-Short & Heat & UV-Long & UV-Short & Heat & UV-Long & UV-Short \\
\hline Day 1 & +++ & +++ & +++ & +++ & ++ & ++ & +++ & + & + \\
\hline Day 5 & +++ & +++ & +++ & +++ & ++ & ++ & +++ & + & + \\
\hline Day 10 & ++ & +++ & +++ & +++ & ++ & ++ & ++ & + & + \\
\hline Day 15 & ++ & ++ & ++ & ++ & ++ & ++ & ++ & + & + \\
\hline Day 20 & ++ & ++ & ++ & ++ & + & ++ & ++ & + & + \\
\hline Day 25 & ++ & ++ & ++ & ++ & + & + & ++ & + & + \\
\hline Day 30 & ++ & ++ & ++ & ++ & + & + & ++ & + & + \\
\hline
\end{tabular}

+++ : Visualized easily, Required less time, Clearly legible. ++: Visualized with slight effort, Required time, Legible. +: Visualized with difficulty, Required longer duration, Slightly legible.

and the writings become invisible. These samples were then kept at normal room temperature and conditions. They were then analysed at regular interval of five days for one month, using different physical (application of heat and visualization under ultraviolet lamp) and chemical (iodine fuming, treatment with phenolphthalein solution and treatment with silver nitrate solution) methods.

\section{Results}

The results of the study on common visualization methods (physical and chemical), for decipherment of secret writings done using different invisible inks, varied as shown in the Tables 1-3.

To find out the sensitivity of the visualization methods over a period of time, the secret writings were analysed at regular interval of five days for one month, using the mentioned physical and chemical methods. The results varied as shown in the Tables 4-9.

The visibility of fruit juices by physical methods, decreased with time. However, grape juice showed constant visibility with UV light (Table 4). Visibility of these juices with chemical methods varied. In some cases, the visibility was almost constant (phenolphthalein treatment and iodine fuming of lemon juice), while in others it was irregular (Table 5).

The visibility of detergent by heat, decreased with time while with UV, it showed a bit irregularity. On the other hand, the visibility of sugar solution and vinegar by heat was found to be constant and irregular, respectively (Table 6). Visibility of detergent by iodine fuming decreased with time, while it was a little irregular in cases 
Table 5: Fruit juices- Visibility with the use of chemical methods.

\begin{tabular}{|c|c|c|c|c|c|c|c|c|c|}
\hline & \multicolumn{3}{|c|}{ Lemon juice } & \multicolumn{3}{|c|}{ Apple juice } & \multicolumn{3}{|c|}{ Grape juice } \\
\hline & $\begin{array}{l}\text { Phenolp- } \\
\text { Hthalein }\end{array}$ & Silver nitrate & lodine fuming & $\begin{array}{l}\text { Phenolp- } \\
\text { hthalein }\end{array}$ & Silver nitrate & lodine fuming & $\begin{array}{l}\text { Phenolp- } \\
\text { hthalein }\end{array}$ & Silver nitrate & lodine fuming \\
\hline Day 1 & ++ & +++ & ++ & - & ++ & ++ & - & - & ++ \\
\hline Day 5 & ++ & ++ & ++ & - & + & ++ & - & - & + \\
\hline Day 10 & ++ & + & ++ & - & + & ++ & - & - & + \\
\hline Day 15 & ++ & ++ & ++ & - & + & ++ & - & - & + \\
\hline Day 20 & ++ & ++ & ++ & - & ++ & + & - & - & + \\
\hline Day 25 & ++ & ++ & ++ & - & ++ & ++ & - & - & ++ \\
\hline Day 30 & + & ++ & ++ & - & + & + & - & - & + \\
\hline
\end{tabular}

$\therefore$ No result.

Table 6: Chemical fluids- Visibility with the use of physical methods.

\begin{tabular}{|c|c|c|c|c|c|c|c|c|c|}
\hline & \multicolumn{3}{|c|}{ Detergent } & \multicolumn{3}{|c|}{ Sugar solution } & \multicolumn{3}{|c|}{ Vinegar } \\
\hline & Heat & UV-Long & UV-Short & Heat & UV-Long & UV-Short & Heat & UV-Long & UV-Short \\
\hline Day 1 & +++ & ++ & ++ & + & - & - & + & - & - \\
\hline Day 5 & +++ & +++ & +++ & + & - & - & ++ & - & - \\
\hline Day 10 & ++ & +++ & +++ & + & - & - & ++ & - & - \\
\hline Day 15 & ++ & +++ & +++ & + & - & - & + & - & - \\
\hline Day 20 & ++ & ++ & + & + & - & - & ++ & - & - \\
\hline Day 25 & + & + & + & + & - & - & ++ & - & - \\
\hline Day 30 & + & + & + & + & - & - & + & - & - \\
\hline
\end{tabular}

Table 7: Chemical fluids- Visibility with the use of chemical methods.

\begin{tabular}{|c|c|c|c|c|c|c|c|c|c|}
\hline & \multicolumn{3}{|c|}{ Detergent } & \multicolumn{3}{|c|}{ Sugar solution } & \multicolumn{3}{|c|}{ Vinegar } \\
\hline & Phenolp-hthalein & Silver nitrate & lodine fuming & Phenolp-hthalein & Silver nitrate & lodine fuming & Phenolp-hthalein & Silver nitrate & lodine fuming \\
\hline Day 1 & ++ & + & +++ & - & - & - & - & - & + \\
\hline Day 5 & ++ & + & +++ & - & - & - & - & - & ++ \\
\hline Day 10 & +++ & + & +++ & - & - & - & - & - & + \\
\hline Day 15 & ++ & +++ & +++ & - & - & - & - & - & + \\
\hline Day 20 & ++ & ++ & ++ & - & - & - & - & - & + \\
\hline Day 25 & + & + & + & - & - & - & - & - & + \\
\hline Day 30 & + & + & + & - & - & - & - & - & + \\
\hline
\end{tabular}

of phenolphthalein and silver nitrate treatment. Iodine fuming of vinegar also showed a bit irregularity, but mostly it gave constant visibility (Table 7).

The visibility of milk by physical methods gave irregular results, however the visibility by UV was only a bit irregular and mostly constant. The visibility of saliva by heat decreased with time, and by UV light it was constant. Sweat exhibited constant visibility with all the three physical methods (Table 8 ). Visibility of milk by phenolphthalein treatment was found to be irregular, while it was constant in case of sweat. Treatment with silver nitrate solution produced irregular results in terms of visibility of all the three bodily fluids. Visibility of milk and saliva by iodine fuming decreased with time, but of sweat, remained constant (Table 9).

\section{Discussion}

Secret writing samples written with different biological, fruits and chemical fluids were deciphered by physical and chemical methods.
Secret writings written with fruit juices, chemicals and bodily fluids turned brown in colour when heated. This is because these fluids are either mildly acidic or alkaline in nature and such an acid or base weakens the paper. The acid or base from these fluids remains in the paper after the water has evaporated and the paper has dried. When the paper is then held near a heat source, these acidic or alkaline parts of the paper burn or turn brown faster before the rest of the paper does, revealing the message written on the paper. These fluids were visible under UV light because of their fluorescence or the differential absorption and reflection of UV rays by them. The reason that lemon juice showed slightly brown fluorescence in most cases, may be due to more concentration of the juice. Iodine fuming of fruit juices revealed secret messages in white colour with purple-brown background because the paper contains starch and when iodine fumes come in contact with the paper, they react with starch and produce purple colour while the fruit juices do not react with the fumes and remain colourless. Thus, they were deciphered as white coloured messages. The purple colour of iodine slowly fades away and become brownish. 
Table 8: Biological fluids- Visibility with the use of physical methods.

\begin{tabular}{|c|c|c|c|c|c|c|c|c|c|}
\hline & \multicolumn{3}{|c|}{ Milk } & \multicolumn{3}{|c|}{ Saliva } & \multicolumn{3}{|c|}{ Sweat } \\
\hline & Heat & UV-Long & UV-Short & Heat & UV-Long & UV-Short & Heat & UV-Long & UV-Short \\
\hline Day 1 & + & + & + & ++ & + & + & + & + & + \\
\hline Day 5 & + & + & + & + & + & + & + & + & + \\
\hline Day 10 & ++ & ++ & + & + & + & + & + & + & + \\
\hline Day 15 & ++ & + & ++ & - & + & + & + & + & + \\
\hline Day 20 & ++ & + & + & - & + & + & + & + & + \\
\hline Day 25 & ++ & + & + & - & + & + & + & + & + \\
\hline Day 30 & ++ & + & + & + & + & + & + & + & + \\
\hline
\end{tabular}

Table 9: Biological fluids- Visibility with the use of chemical methods.

\begin{tabular}{|c|c|c|c|c|c|c|c|c|c|}
\hline & \multicolumn{3}{|c|}{ Milk } & \multicolumn{3}{|c|}{ Saliva } & \multicolumn{3}{|c|}{ Sweat } \\
\hline & Phenolp-hthalein & $\begin{array}{l}\text { Silver } \\
\text { nitrate }\end{array}$ & $\begin{array}{l}\text { lodine } \\
\text { fuming }\end{array}$ & Phenolp-hthalein & $\begin{array}{c}\text { Silver } \\
\text { nitrate }\end{array}$ & $\begin{array}{l}\text { lodine } \\
\text { fuming }\end{array}$ & Phenolp-hthalein & $\begin{array}{l}\text { Silver } \\
\text { nitrate }\end{array}$ & $\begin{array}{l}\text { lodine } \\
\text { Fuming }\end{array}$ \\
\hline Day 1 & ++ & + & ++ & - & ++ & ++ & + & + & + \\
\hline Day 5 & ++ & + & ++ & - & + & + & + & + & + \\
\hline Day 10 & +++ & ++ & ++ & - & ++ & + & + & + & + \\
\hline Day 15 & +++ & + & ++ & - & + & + & + & + & + \\
\hline Day 20 & ++ & ++ & ++ & - & + & + & + & + & + \\
\hline Day 25 & +++ & ++ & ++ & - & - & - & + & ++ & + \\
\hline Day 30 & +++ & ++ & + & - & - & - & + & ++ & + \\
\hline
\end{tabular}

Iodine fuming of chemical and biological fluids revealed the writing in brown colour. This is because, these fluids disturb the surface fibres of the paper, so when iodine fuming is done, the iodine sticks preferentially to the disturbed areas of the paper and gives a brown appearance. The oils present in the sweat, also absorb the iodine fumes and appear brownish. Some of the invisible inks appeared transparent when treated with phenolphthalein solution. This may be due to the fact that these fluids are mildly acidic in nature and phenolphthalein is colourless in acidic condition. Another reason may be that, these mildly acidic fluids weaken the paper at places where they are applied and those weakened or thinned areas of paper become wet than the rest parts and thus appear transparent when phenolphthalein solution is applied on them. The latter reason may also be given for the transparent and colourless writings revealed on treatment with silver nitrate solution. The appearance of brown colour in case of apple juice, when treated with silver nitrate solution, may be due to some chemical reaction between silver nitrate and certain salt present in the juice. As we know that, certain salts react with silver nitrate and produce a silver salt that decomposes to silver metal on exposure to light and this metallic silver gives brown colour. Probably, this reaction might have occurred in the case of apple juice. The brown colour also intensified a bit, on exposure to light, just like it occurs in case of metallic silver, which confirms this result.

The visibility of the invisible inks used in this project, differed over a period of one month. Although, some of the inks showed neither decrease nor increase in their visibility for the whole month. The visibility of some of the inks, as expected, decreased with time. The obvious reason may be the fading of these inks with time. However, some inks showed irregularity in their visibility, which may be due to different factors, such as extra deposition of the inks, abrasion at the written surface, variation in the concentration of the inks, their absorption by paper, uneven application of the inks, etc. The constant visibility exhibited by some of the inks may be because they require longer than one month for their fading.

\section{Conclusion}

From the results obtained in this study, it could be concluded that the secret writings written with different fruit juices, chemical and biological fluids can be deciphered by physical and chemical methods. Among physical methods, heating is the best for deciphering these fluids as it does not take much time and the document is also not affected if it is heated carefully. Visualization under UV light also doesn't ruin the document, but all the invisible inks cannot be visualized easily under it, so it becomes time consuming and will require effort for the visibility of messages. Among chemical methods, iodine fuming is the best because it does not spoil the documents extensively, like the phenolphthalein and silver nitrate solution does, for further testing. The purple colour of iodine fades away after a few minutes. However, it requires a little more time than heat treatment to develop the secret messages. Both of these methods give good results up to one month. Further studies considering a larger sample size and considering more factors will help gain a better understanding of the visualization methods most suitable for developing secret writing.

\section{References}

1. http://www.faqs.org/espionage/Re-Se/Secret-Writing.html (2017).

2. Andharmule D, Kapoor N, Badiye A. An Evaluation of Some commonly used Methods for Visualization of Secret Writing. Research Journal of Forensic Sciences. 2013; 1: 1-4.

3. Sharma BR. Forensic Science in Criminal Investigation and Trials. $4^{\text {th }}$ ed. Universal Law Publishing Co. Pvt. Ltd. 2005.

4. www.wisegeek.com/what-is-invisible-ink.htm (2017). 
5. http://www.artofmanliness.com/2011/09/09/man-knowledge-the-history-ofinvisible-ink/ (2017).

6. http://www.encyclopedia.com/doc/1G2-3403300676.html

Austin J Forensic Sci Criminol - Volume 4 Issue 2 - 2017

ISSN : 2380-0801 | www.austinpublishing group.com

Sahu et al. (C) All rights are reserved
Citation: Hussain SS and Sahu M. A Study on Common Visualization Methods for Secret Writing done by Invisible Inks and their Sensitivity Over a Period of Time. Austin J Forensic Sci Criminol. 2017; 4(2): 1061. 